\title{
Effect of Interlukin-I $\beta$ on proliferation of gastric epithelial cells in culture
}

\author{
Ian LP Beales
}

Address: Department of Cell Biology School of Medicine, Health Policy and Practice, University of East Anglia Norwich, NR4 7TJ, United Kingdom E-mail: ibeales@uea.ac.uk

Published: 5 April 2002

BMC Gastroenterology 2002, 2:7
Received: 30 November 2001

Accepted: 5 April 2002

This article is available from: http://www.biomedcentral.com/I47I-230X/2/7

(C) 2002 Beales; licensee BioMed Central Ltd. Verbatim copying and redistribution of this article are permitted in any medium for any purpose, provided this notice is preserved along with the article's original URL.

\begin{abstract}
Background: Helicobacter pylori is the main risk factor for the development of non-cardia gastric cancer. Increased proliferation of the gastric mucosa is a feature of $H$. pylori infection. Mucosal interkeukin-I $\beta$ production is increased in $H$. pylori infection and IL- I $\beta$ genotypes associated with increased pro-inflammatory activity are risk factors for the development of gastric cancer. The effect of IL-I $\beta$ on gastric epithelial cell proliferation has been examined in this study.

Methods: AGS cells were cultured with IL-I $\beta$. DNA synthesis was assed by $\left[{ }^{3} \mathrm{H}\right]$ thymidine incorporation and total viable cell numbers by MTT assay.

Results: IL-I $\beta$ dose dependently increased DNA synthesis and cell numbers. The enhanced proliferation was blocked by interleukin-I receptor antagonist. Addition of neutralising antibody to GM-CSF reduced IL-I $\beta$-stimulated proliferation by $3 I \pm 4 \%$. GM-CSF alone significantly stimulated proliferation. Addition or neutralisation of IL-8 had no effect on basal or IL-I $\beta$-stimulated proliferation. The tyrosine kinase inhibitor genistein completely blocked IL-I $\beta$-stimulated proliferation and inhibition of the extracellular signal related kinase pathway with PD 98059 inhibited IL-I $\beta$ stimulated proliferation by $58 \pm 5 \%$.

Conclusions: IL-I $\beta$ stimulates proliferation in gastric epithelial cells. Autocrine stimulation by GMCSF contributes to this proliferative response. Signalling via tyrosine kinase activity is essential to the mitogenic response to IL-I $\beta$. The extracellular signal related kinase pathway is involved in, but not essential to downstream signalling. IL-I $\beta$ may contribute to the hyperproliferation seen in $H$. pylori- infected gastric mucosa, and be involved in the carcinogenic process.
\end{abstract}

\section{Background}

Helicobacter pylori is believed to be the major aetiological factor in the development of non-cardia gastric adenocarcinoma. Large-scale epidemiological studies have confirmed a strong association between $H$. pylori infection and both cancer [1-3] and the earlier histological stages, atrophy and intestinal metaplasia [4,5]; both of which increase the risk of later neoplastic transformation. Animal models have also demonstrated the importance of $H$. $p y$ - lori in gastric carcinogenesis [6,7]. Increased rates of proliferation of the gastric mucosa are typical in $H$. pylori infection [8-11], and hyperproliferation within the gastrointestinal tract appears to be a marker for later malignant change [12]. The cause of the increased rate of proliferation is not clear, but the increased rates reduce to normal with clearance of the infection $[8,13]$. Although hypeprproliferation is typical in vivo, studies testing the effects of $H$. pylori or its products in vitro have shown con- 
flicting results, with both enhanced $[14,15]$ and diminished [16-18] proliferation reported. It is possible that other components of the inflammatory response typical of $H$. pylori infected mucosa could be at least partly responsible for driving the increased cell proliferation.

The pluripotent pro-inflammatory cytokine interleukin$1 \beta$ has a central role in the pathogenesis of $H$. pylori-induced mucosal inflammation. IL-1 $\beta$ gene expression and protein production are increased in $H$. pylori infection and reduce with successful eradication $[19,20]$. The presence of the IL-1 $\beta$ genotype polymorphism associated with enhanced IL-1 $\beta$-production has been associated with a significant increased risk of gastric cancer and pre-cancerous lesions $[21,22]$. Interleukin- $1 \beta$ is a potent inhibitor of gastric acid secretion and it is hypothesized that the enhanced IL- $1 \beta$ response alters the topography of the gastric infection and thus promotes inflammation and subsequent atrophy of the gastric corpus $[23,24]$. The possibility that IL-1 $\beta$ itself drives the increased proliferation of gastric epithelial cells has not been fully investigated. Alteration of gastric proliferation by IL- $1 \beta$ might contribute to the carcinogenic process, in addition to effects on acid secretion. Therefore the direct effects of IL- $1 \beta$ on gastric epithelial proliferation have been assessed.

The mitogen-activated protein kinase (MAPK) cascades are well-characterised pathways transducing signals from the cell surface to the nucleus. The family includes distinct subgroups; extracellular signal-related kinases (ERKs), cJun $\mathrm{NH}_{2}$-terminal kinases (JNKs) and p38 MAPK [25]. The ERKs are activated by a variety of extracellular stimuli, and mediate the pro-proliferative effects of a number of hormones and growth factors $[26,27]$. Activation by phosphorylation of a dual specificity protein kinase (MAP kinase kinase (MAPKK)), (also known as MEK), allows it in turn to activate a family of serine-threonine protein kinases, known as the ERKs. The ERKs in turn phosphorylate numerous cellular proteins including transcription factors and thus have a central role in propagation of mitogenic signals. Accordingly the role of the MAP-kinase pathway in mediating the responses to IL- $1 \beta$ has been assessed.

\section{Methods \\ Cell culture}

The human AGS gastric carcinoma cell line was purchased from the European Collection of Animal Cell Cultures (Porton Down, UK). Cells were grown in monolayer culture in RPMI 1640 medium supplemented with $100 \mu \mathrm{g} /$ $\mathrm{ml}$ penicillin, $100 \mu \mathrm{g} / \mathrm{ml}$ streptomycin, $100 \mu \mathrm{g} / \mathrm{ml}$ gentamicin, $2.5 \mu \mathrm{g} / \mathrm{ml}$ amphoteracin B and $10 \%$ foetal calf serum. Cells were grown in $75 \mathrm{~cm}^{2}$ tissue culture flasks at $37^{\circ} \mathrm{C}$ in an atmosphere of $5 \% \mathrm{CO}_{2}$ and $95 \%$ air and passaged every 5-7 days.

\section{Proliferation studies}

$\left[{ }^{3} \mathrm{H}\right]$ thymidine incorporation. Cells were grown in media containing $10 \%$ foetal calf serum, plated into 24 -well plates at $10^{5}$ cells/well and allowed to attach overnight. After washing with serum-free media, cells were incubated in serum free medium containing $0.2 \mathrm{mM}$ unlabelled thymidine for 24 hours in the presence of increasing concentrations of IL-1 $\beta$, IL-8 or GM-CSF. DNA synthesis was estimated by measurement of $\left[{ }^{3} \mathrm{H}\right]$ thymidine incorporation into the trichloroacetic acid (TCA) precipitable material [28]. $\left[{ }^{3} \mathrm{H}\right]$ thymidine $(0.1 \mu \mathrm{Ci} / \mathrm{ml}, 10 \mathrm{Ci} / \mathrm{mmol})$ was added 2 hours before the end of a 24 hour treatment period. Cells were washed twice with serum-free medium to remove unincorporated $\left[{ }^{3} \mathrm{H}\right]$ thymidine, and DNA was precipitated with $5 \% \mathrm{TCA}$ at $4^{\circ} \mathrm{C}$ for 15 minutes. The precipitates were then washed twice with $95 \%$ ethanol, dissolved in $1 \mathrm{ml}$ of $\mathrm{NaOH}$, and analysed by liquid scintillation counting. Results are expressed as percent control unstimulated $\left[{ }^{3} \mathrm{H}\right]$ thymidine incorporation (mean \pm SD) of 4-6 different experiments, each performed in triplicate. For the detection of growth inhibition, cells were incubated with either the specific MEK inhibitor PD $98059(25 \mu \mathrm{M})$ [29], IL-1 receptor antagonist $(500 \mathrm{ng} / \mathrm{ml})[30]$ or the neutralising antibodies, anti-GMCSF $(5 \mu \mathrm{g} / \mathrm{ml})$ or anti-IL-8 $(10 \mu \mathrm{g} / \mathrm{ml})$. Inhibitors or antibodies were added 30 minutes prior to cytokines.

\section{Cell growth}

Total viable cell numbers were assessed by a modified MTT (3-[4,5-dimethylthiazol-2-yl]-2.5 diphenyl tetrazolim bromide assay) [31]. Cells were plated into 24-well plates in medium containing $10 \%$ foetal calf serum. After attachment overnight, the medium was changed to $1 \%$ foetal calf serum-supplemented medium and increasing concentrations of IL-1 $\beta$ were added. Cells were cultured for 48 hours and then the medium was removed and fresh RPMI 1640 medium containing $0.5 \mathrm{ng} / \mathrm{ml}$ MTT was added. Cells were incubated at $37^{\circ} \mathrm{C}$ for 3 hours. The medium was then removed and $0.04 \mathrm{M} \mathrm{HCl}$ in isopropanol was added to extract the reduced formazan product. The resulting optical density at $550 \mathrm{~nm}$ was determined.

\section{Chemicals and reagents}

Recombinant human IL-1 $\beta$ and IL-8 were purchased from Sigma (Poole, UK), recombinant human GM-CSF and IL1 receptor antagonist, anti-GM-CSF and anti-IL-8 were from R and D systems (Abingdon, Uk). PD 95059 was from Calbiochem (Nottingham, UK). RPMI 1640 was from Gibco BRL (Paisley, UK) and all other reagents were from Sigma. Concentrations of inhibitors used were taken from manufacturers' data and published data. The ability

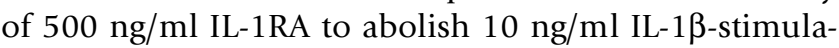
tion of IL-8 secretion in AGS cells was confirmed. The efficacy of the anti-GM-CSF at $5 \mu \mathrm{g} / \mathrm{ml}$ antibody to abolish 


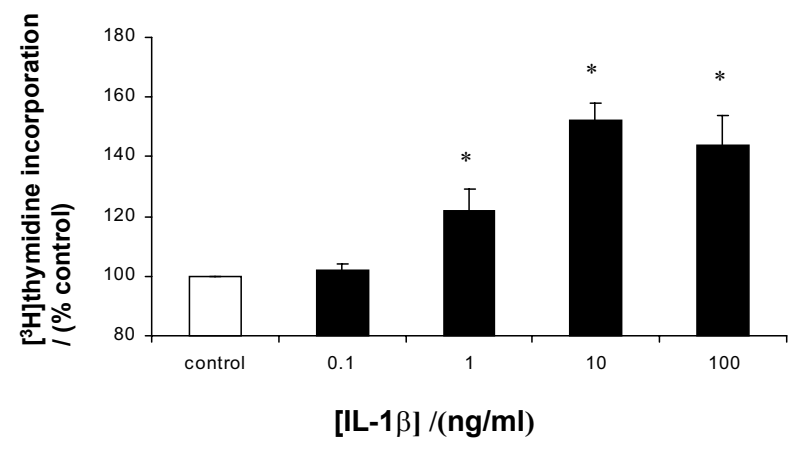

Figure I

Effect of IL-I $\beta$ on $\left[{ }^{3} \mathrm{H}\right]$ thymidine incorporation into gastric epithelial AGS cells Cells were treated with increasing concentrations of IL-I $\beta$ for 24 hours and DNA synthesis assessed by $\left[{ }^{3} \mathrm{H}\right]$ thymidine incorporation. Results expressed as means \pm standard deviation. ${ }^{*} P<0.01$ vs. control

GM-CSF (1 ng/ml) induced AGS cell proliferation was confirmed.

\section{Statistics}

Cytokine-stimulated results where compared with control unstimulated cells on the same 24-well plate. Data were compared by one-way analysis of variance and Student's t-test to determine statistical significance. Each experiment as performed in triplicate on 4-6 occasions. Results are expressed as mean \pm standard deviation. Differences with $P$ values of $<0.05$ were considered significant.

\section{Results}

\section{Effect of IL-I $\beta$ on $\left[{ }^{3} \mathrm{H}\right]$ thymidine incorporation}

Interleukin- $1 \beta$ caused a dose-dependent increase in DNA synthesis as measured by thymidine incorporation. As shown in figure 1 , significant stimulation was seen with $1-100 \mathrm{ng} / \mathrm{ml}$ IL-1 $\beta$. The maximal stimulation of $52 \pm 6 \%$ above control was seen with $10 \mathrm{ng} / \mathrm{ml}$. The higher dose of $100 \mathrm{mg} / \mathrm{ml}$ was slightly less effective in stimulating proliferation.

\section{Effect of IL-I $\beta$ on cell number}

The increase in DNA synthesis by IL- $1 \beta$ was translated into an absolute increase in viable cell numbers. As shown in figure 2, IL-1 $\beta$ increased cell numbers in a dose-dependent manner similar to the effects on $\left[{ }^{3} \mathrm{H}\right]$ thymidine incorporation. The maximal stimulation was again seen at $10 \mathrm{ng} / \mathrm{ml}$ of IL-1 $\beta$, which produced a $22 \pm 5 \%$ increase in total cell number.

Effects of cytokine inhibition or receptor antagonism on IL-I $\beta$-stimulation of proliferation

Pretreatment of the cells with interleukin-1 receptor antagonist abolished the stimulatory effects of IL-1 $\beta$ on

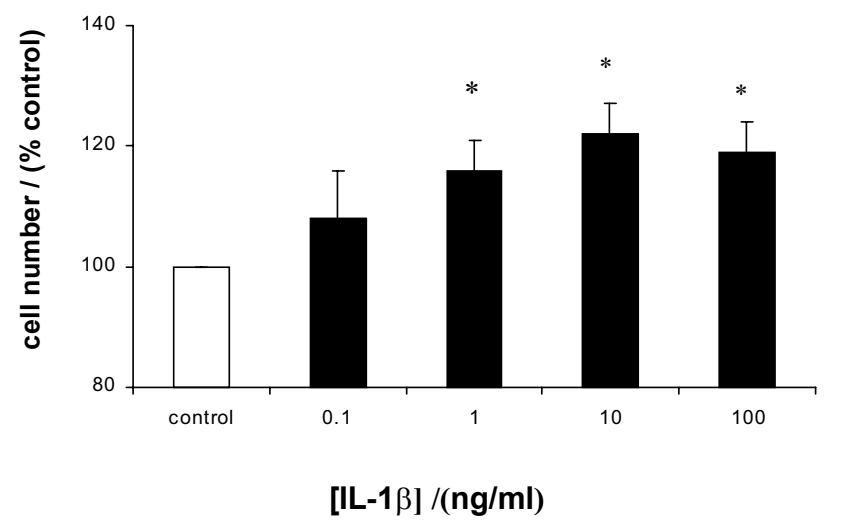

Figure 2

Effect of IL-I $\beta$ on cell numbers of gastric epithelial cells Cells were treated with increasing concentrations of IL-I $\beta$ for 48 hours and total viable cell numbers assessed by MTT assay. Results expressed as means \pm standard deviation. ${ }^{*} P<0.01$ vs. control

$\left[{ }^{3} \mathrm{H}\right]$ thymidine incorporation (Figure 3). Previous studies have shown that IL-1 $\beta$ can activate gastric epithelial cells, including AGS cells, to secrete other cytokines, particularly interleukin-8 and granulocyte-macrophage colony stimulating factor (GM-CSF)[31,32]. Therefore further studies were undertaken to assess if the stimulatory actions of IL- $1 \beta$ were mediated by either of these two cytokines. Neutralising antibodies to either IL- 8 or GM-CSF had no effect on unstimulated $\left[{ }^{3} \mathrm{H}\right]$ thymidine incorporation. Neutralisation of IL- 8 had no effect on IL-1 $\beta$ stimuated growth but the anti-GM-CSF antibody reduced IL-1 $\beta$-stimulated proliferation by $31 \pm 4 \%(P<0.01)$ (figure 3 ).

\section{Effects of GM-CSF on proliferation}

In view of the results obtained with the anti-GM-SCF antibody, the direct growth-stimulatory actions of GM-CSF were examined. GM-CSF had a potent growth stimulatory action on AGS cells: significant enhancement of $\left[{ }^{3} \mathrm{H}\right]$ thymidine incorporation was seen at all concentrations (0.001-100 ng/ml) of GM-CSF. GM-CSF itself appeared to be a more potent stimulant than IL- $1 \beta$; maximal stimulation of $108 \pm 17 \%$ above control was seen with 100 $\mathrm{ng} / \mathrm{ml}$ of GM-CSF (Figure 4 ). The inhibitory action of the anti-GM-CSF antibody was confirmed by abolition of the growth stimulatory action of $1 \mathrm{ng} / \mathrm{ml}$ GM-CSF (data not shown). Previous studies have shown that IL-1 $\beta$-stimulated GM-CSF release under similar conditions in AGS cells to be approximately 10-20 pg/well/24 hours [32]. To confirm the results obtained with the anti-IL-8 antibody, $\left[{ }^{3} \mathrm{H}\right]$ thymidine incorporation was measured in response to IL-8. No enhancement of proliferation was seen at any concentration of IL-8 (0.001-100 ng/ml) (data not 


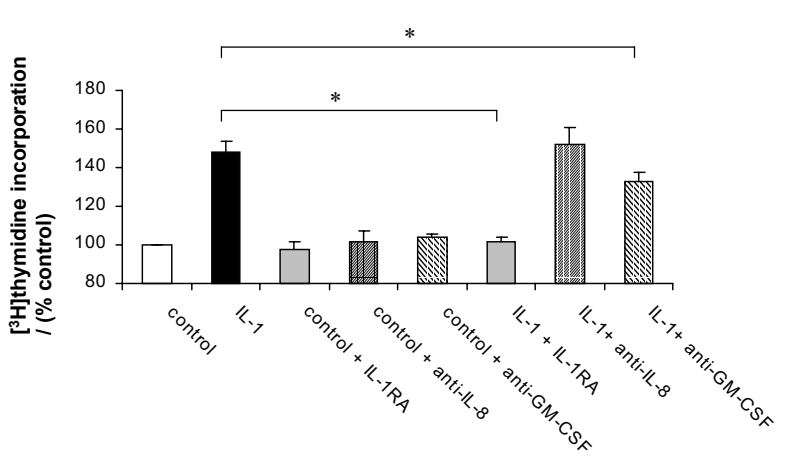

Figure 3

Effect of cytokine inhibition on IL-I $\beta$-stimulation of $\left[{ }^{3} \mathrm{H}\right]$ thymidine into gastric epithelial cells AGS cells were treated with $10 \mathrm{ng} / \mathrm{ml} \mathrm{IL-I} \beta$ for 24 hours plus either interleukin-I receptor antagonist (IL-IRA $500 \mathrm{ng} / \mathrm{ml}$ ), neutralising anti-IL-8 antibody $(10 \mu \mathrm{g} / \mathrm{ml})$ or neutralising anti-GM-CSF antibody (5 $\mu \mathrm{g} / \mathrm{ml})$. DNA synthesis was assessed by $\left[{ }^{3} \mathrm{H}\right]$ thymidine incorporation. Results expressed as means \pm standard deviation. ${ }^{*} P<0.0$ I vs. IL-I $\beta$ stimulation in absence of inhibitor.

shown). Under similar conditions IL-1 $\beta$-stimulated IL-8 release is approximately $3000 \mathrm{pg} /$ well/24 hours [31].

\section{Mechanism of IL-I $\beta$-stimulation of cell proliferation}

The specific inhibitors genistein, which inhibits tyrosine kinases and PD 98059, which inhibits MAP kinase kinase (MEK), and thus inhibits the ERK-pathway, were used to assess the possible intracellular pathways mediating the effects of IL- $1 \beta$. In order to examine the effects of IL-1 $\beta$ distinct from those of GM-CSF, these experiments were performed in the presence of the anti-GM-CSF neutralising antibody. As shown in figure 5, neither genistein nor PD 98059 altered unstimulated $\left[{ }^{3} \mathrm{H}\right]$ thymidine incorporation. Genistein completely abolished the IL-1 $\beta$-stimulation of proliferation. Inhibition of MEK with PD 98059 reduced IL-1 $\beta$-stimulated proliferation by $58 \pm 5 \%(\mathrm{P}<$ 0.01 ) (figure 5) but did not completely abolish the growth stimulatory action of IL-1 $\beta$. Further increases to supramaximal concentrations of PD 98050 did not further inhibit IL-1 $\beta$-stimulated proliferation (data not shown).

\section{Discussion}

This study demonstrated that IL- $1 \beta$ increased proliferation of AGS cells. This effect was reversed by the receptor antagonist, suggesting it was mediated via the interleukin1 receptor. IL- $1 \beta$ stimulated both $\left[{ }^{3} \mathrm{H}\right]$ thymidine incorporation, as a measure of stimulation of DNA synthetic rate and also total cell numbers as measured by the MTT assay. This illustrates that the stimulation of DNA synthesis by IL- $1 \beta$ is translated into a real increase in cell numbers.

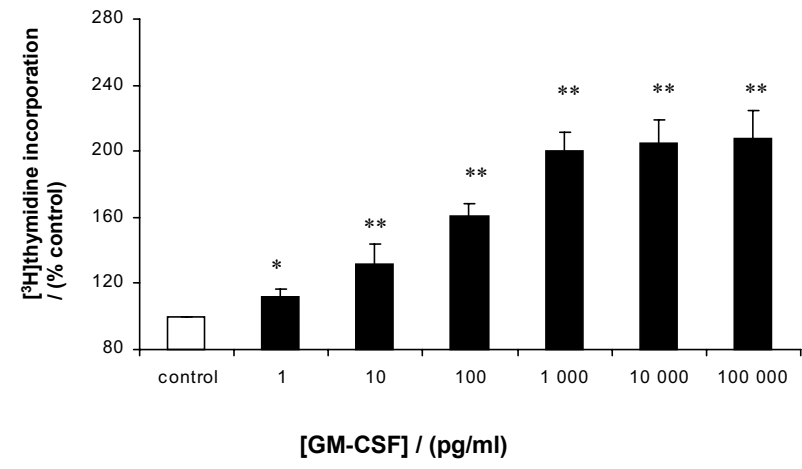

Figure 4

Effect of GM-CSF on proliferation of gastric epithelial cells. AGS cells were treated with increasing concentrations of GM-CSF for 24 hours. Cell proliferation was assessed by $\left[{ }^{3} \mathrm{H}\right]$ thymidine incorporation. Results expressed as means \pm standard deviation. ${ }^{*} P<0.05,{ }^{* *} P<0.01$ vs control

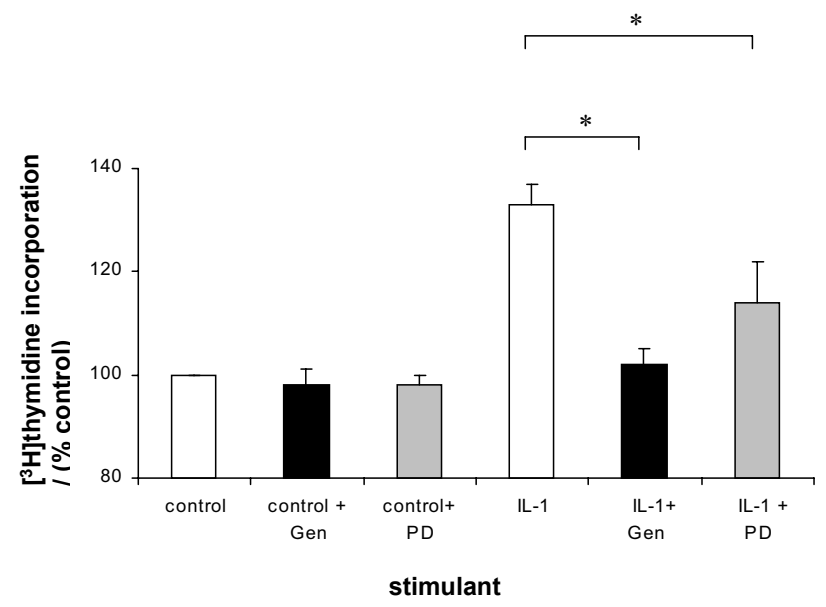

Figure 5

Effect of inhibition of tyrosine kinase and MEK activity on ILI $\beta$-stimulated gastric epithelial cell proliferation. AGS cells were treated with $10 \mathrm{ng} / \mathrm{ml} \mathrm{IL-I} \beta$ for 24 hours in the presence of the tyrosine kinase inhibitor genistein (100 $\mu \mathrm{M})$ or the MEK inhibitor PD $98059(25 \mu \mathrm{M})$. Proliferation was assessed by $\left[{ }^{3} \mathrm{H}\right]$ thymidine incorporation. Studies were performed in the presence of anti-GM-CSF antibody $(5 \mu \mathrm{g} / \mathrm{ml})$. Results expressed as means \pm standard deviation. ${ }^{*} P<0.01$ vs control

A portion of the stimulatory action of IL-1 $\beta$ appears to be indirect. Neutralisation of GM-CSF in the media led to a significant reduction of IL-1 $\beta$-stimulated proliferation. AGS cells are known to secrete GM-CSF in response to IL$1 \beta$ [32]. GM-CSF itself was a potent stimulant of cell proliferation. Thus it seems likely that part of the growth stimulatory actions of IL- $1 \beta$ are due to an autocrine inter- 
mediary action of GM-CSF. There are limited previous data suggesting that GM-CSF stimulates the proliferation of non-haematopoietic cells; Dippold et al showed that exogenous GM-CSF stimulated the growth of two out of two cultures derived from gastric carcinomas and two out of nine pancreatic carcinoma cell lines $[33,34]$. However, unlike the current study, autocrine production of GM-CSF was no detectable.

Gastric epithelial cells also produce IL-8 in response to IL$1 \beta$ [31]. However in this model system, IL-8 alone had no pro-proliferative action and neutralisation of IL-8 did not affect the stimulatory action of IL-1 $\beta$. Therefore it is unlikely that IL-8 has an autocrine role in the growth-stimulatory action of IL-1 $\beta$. It is possible that other cytokines produced by the gastric epithelial cells in response to IL$1 \beta, H$. pylori or other inflammatory insults could also play a role as autocrine or paracrine mediators of growth. It has recently been reported that another $\mathrm{C}-\mathrm{X}$-C chemokine, GRO/CINC-1, which is also upregulated in H. pylori infection stimulated proliferation in rat gastric epithelial cells [35]. The role of these other potential autocrine mediators deserves further study.

The results of the inhibitor studies strongly suggest that tyrosine kinase activity is essential for the growth promoting action of IL-1 $\beta$ in AGS cells. The tyrosine kinase inhibitor genistein abolished the stimulatory action of IL-1 $\beta$. IL-1 $\beta$ is known to activate a plethora of intracellular signalling pathways [31,36-39], but in the current situation there appears to be an absolute requirement for signalling via a tyrosine kinase, subsequent on receptor activation.

The mitogen-activated protein cascade is a well-characterised pathway mediating the cell growth-stimulatory actions of many growth factors and hormones. Inhibition of the ERK pathway, with the MEK inhibitor PD 98059, which prevents activation of ERKs by phosphorylation, had a significant inhibitory action against the stimulatory action of IL-1 $\beta$. This suggests that activation of the ERK pathway is important in mediating the growth stimulatory actions of IL-1 $\beta$. Activation of MAP kinase cascades, including the p42 and p44 ERK pathways and p46JNK and p55JNK c-Jun $\mathrm{NH}_{2}$-terminal kinases by IL-1 $\beta$ has been demonstrated in rat gastric epithelial cells $[41,42]$, but the functional importance of these pathways was not examined. Activation of ERKs and JNKs was inhibited by genistein [41], consistent with the inference of the current study that MAPKs lie downstream of tyrosine activity in IL-1 $\beta$-induced signalling. However in the current study PD 98059 did not completely abolish the stimulatory action of IL- $1 \beta$, suggesting that alternative pathways, activated subsequent on tyrosine kinase activity, also play a role in the signalling of the proliferative responses to IL-1 $\beta$. Further studies are underway at present to examine these.
There are conflicting data available concerning the direct effects of IL-1 $\beta$ on gastric epithelial proliferation. Although the current study and the study by Fan et al using stimulated-leukocyte conditioned media showed increased proliferation of the human AGS cell line [14], others have shown inhibition of serum, TGF- $\alpha$ and EGFstimulated proliferation in RGM1 rat gastric epithelial cells by IL- $1 \beta[41,42]$. Tominaga et al showed that pretreatment of RGM1 cells with IL- $1 \beta$ for 6 hours inhibited proliferation at 24 hours, but the inhibitory effect was lost at 48 hours, [41]. The reasons for these discrepancies are not clear. They may reflect intrinsic differences between the cell lines, differences in activation and involvement of paracrine growth-promoting pathways, species variability, an effect specific for certain growth factors, or underlying differences in the biology of cell lines derived from cancer (AGS) or normal tissue (RGM1). The studies demonstrating inhibition of proliferation by IL- $1 \beta$ were performed in the presence of powerful growth-promoting stimuli (high serum or specific growth factor concentrations in the culture media), whist the current studies were performed in serum-free or $1 \%$ serum media. It is possible that the multiple signalling pathways activated by IL- $1 \beta$ have differing effects on proliferation, the dominant effect depending on the complex inter-relationships of stimuli and signalling pathways under different circumstances. Pro-inflammatory cytokines such as IL- $1 \beta$ and TNF- $\alpha$ activate different signalling pathways with divergent results and different time-courses in gastric endocrine and parietal cells $[37,38,43-46]$. Further studies are underway examining the specific roles of the various signalling pathways in gastric epithelial cells under different conditions.

There are now strong epidemiological data linking $H$. $p y$ lori with gastric carcinoma. The carcinogenic process appears to involve a number of steps: $H$. pylori-induced inflammation progresses to atrophy, intestinal metaplasia, dysplasia and eventually carcinoma [47]. Similarly $H$. pylori infection in Mongolian gerbils readily induces gastric atrophy and cancer [6]. Whilst gastric carcinogenesis is undoubtedly a multifactorial process, involving pathogenic bacterial and host factors, including HLA status, diet and antioxidant status $[47,48]$, it is clear that increased gastric epithelial proliferation, especially when relatively increased compared to apoptosis, is an important part of the pathway $[49,50]$. Increased gastric epithelial proliferation is typical of H. pylori infection; it is demonstrable throughout all stages of the infection and eradication of the infection reduces proliferation. Increased proliferation is an important marker of increased risk of gastrointestinal adenocarcinoma [12]. The mechanisms of the increased proliferation are not completely understood. In vitro studies testing cultures of $H$. pylori or constituents have given conflicting results in different systems, with different cell types and bacterial strains. Direct stimula- 
tion of gastric epithelial proliferation by H. pylori has been reported by some authors $[14,15]$, whilst either neutral effects [15] or increased apoptosis and decreased proliferation have been reported by others [16-18]. Fan et al reported that conditioned media from either $H$. pylori or mitogen activated lymphocytes directly stimulated AGS cell proliferation [14], suggesting that the inflammatory response could be partly responsible for the enhancement of epithelial proliferation. IL- $1 \beta$ production is enhanced in $H$. pylori infection and this cytokine is regarded as being central to the regulation of the pro-inflammatory response in $H$. pylori infection.

IL- $1 \beta$ is a profound inhibitor of gastric acid secretion in vi$v o[51]$ and in isolated parietal cells $[37,38]$. Genetic polymorphisms of the IL-1 $\beta$ gene cluster causing increased transcriptional activity are associated with an increased risk of pre-cancerous and cancerous histological changes in $H$. pylori infection $[21,22]$. The general hypothesis explaining this observation has been that enhanced IL-1 $\beta$ production consequent on $H$. pylori infection is responsible for greater suppression of acid secretion, which in turn allows greater colonisation of the acid-secreting body mucosa [24]. This greater colonisation provokes further inflammation, which ultimately leads to loss of specialised acid-secretory epithelium (atrophy) and further potentiates the vicious cycle of increased inflammation and diminished acid secretion [52]. Gastric atrophy significantly predisposes to cancer [3]. It is believed that atrophy in combination with mediators released in inflammation such as oxygen free radicals and nitric oxide, diet, anti-oxidant state and possibly bacterial overgrowth and generation of nitrosamines in the achlorhydric stomach [53] advance the histological changes, cause mutageneisis and drive progression to cancer.

An alternative, but not mutually exclusive, hypothesis is that the enhanced cytokine response directly enhances epithelial cell proliferation and itself predisposes to cancer, in addition to the effects on acid secretion. The increased cell turnover of this hyperproliferative response would itself make the mucosa more vulnerable to the mutagenic effects of free radicals and other toxic products generated in the achlorhydric inflamed stomach.

Elsewhere in the gastrointestinal tract, IL-1 $\beta$ has been shown to stimulate $\left[{ }^{3} \mathrm{H}\right]$ thymidine incorporation and increase cell number of cultured human colonic subepithelial myofibroblasts, which is thought to have importance in the remodelling of the mucosa in inflammation [54]. The pro-proliferative effects of IL-1 $\beta$ in the gastrointestinal tract deserve further study, given the importance of this cytokine in the regulation of the mucosal inflammatory response.

\section{Conclusions}

The results of the current study suggest that IL- $1 \beta$ and GMCSF can directly stimulate gastric epithelial proliferation. This might explain the proliferative responses to conditioned lymphocyte media demonstrated by Fan et al[14]. Enhanced epithelial proliferation due to IL-1 $\beta$ may contribute to the enhanced risk of gastric cancer and precancerous lesions in $H$. pylori-infected individuals with specific IL-1 $\beta$ alleles associated with higher levels of production. IL-1 $\beta$ stimulates proliferation via receptor-mediated activation of a tyrosine kinase pathway. Downstream signalling involves ERK-dependent and -independent pathways.

Further studies will be necessary to clarify the mechanisms involved in IL-1 $\beta$-stimulation of gastric epithelial proliferation, as well as data correlating IL- $1 \beta$ genotype, IL- $1 \beta$ protein production and epithelial proliferation in vivo. These will compliment the current study and further enhance our understanding of $H$. pylori-induced gastric carcinogenesis.

\section{List of abbreviations}

EGF - epidermal growth factor; ERK - extracellular signal related kinase; GM-CSF - granulocyte-macrophage colony stimulating factor; IL - interleukin; JNK - c-Jun $\mathrm{NH}_{2}$-terminal kinase; MAP - mitogen activated protein; MTT - 3[4,5-dimethylthiazol-2-yl]-2.5 diphenyl tetrazolim bromide; TCA - trichloroacetic acid; TGF- $\alpha$ - transforming growth factor alpha.

\section{Competing interests}

None declared.

\section{References}

I. An international association between Helicobacter pylori infection and gastric cancer. The EUROGAST Study Group. Lancet 1993, 341:1359-1362

2. Parsonnet J, Friedman GD, Vandersteen DP, Chang Y, Vogelman JH, Orentreich N, Sibley RK: Helicobacter pylori infection and the risk of gastric carcinoma. $N$ Eng J Med I99|, 325: | |27-| | 3 |

3. Uemura N, Okamoto S, Yamamoto S, Matsumura N, Yamaguchi S, Yamakido M, Taniyama K, Sasaki N, Schlemper RJ: Helicobacter pylori infection and the development of gastric cancer. $N$ Eng J Med 200I, 345:784-9

4. Fox JG, Correa P, Taylor NS, Thompson N, Fontham E, Janney F, Sobhan $M$, Ruiz B, Hunter F: High prevalence and persistence of cytotoxin-positive Helicobacter pylori strains in a population with high prevalence of atrophic gastritis. Am J Gastroenterol 1992, 87: I 554-I 560

5. Beales I, Crabtree JE, Scunes D, Covacci A, Calam J: Antibodies to CagA protein are associated with gastric atrophy in Helicobacter pylori infection. Eur J Gastroenterol Hepatol 1996, 8:645-649

6. Watanabe T, Tada M, Nagai H, Sasaki S, Nakao M: Helicobacter pylori infection induces gastric cancer in mongolian gerbils. Gastroenterology 1998, I I 5:642-648

7. Wang TC, Dangler CA, Chen D, Goldenring JR, Koh T, Raychowdhury R, Coffey RJ, Ito S, Varro A, Dockray GJ, et al: Synergistic interaction between hypergastrinemia and Helicobacter infection in a mouse model of gastric cancer. Gastroenterology 2000, I | 8:36-47

8. Lynch DA, Mapstone NP, Clarke AM, Sobala GM, Jackson P, Morrison L, Dixon MF, Quirke P, Axon AT: Cell proliferation in Helico- 
bacter pylori associated gastritis and the effect of eradication therapy. Gut 1995, 36:346-350

9. Lynch DA, Mapstone NP, Clarke AM, Jackson P, Moayyedi P, Dixon MF, Quirke P, Axon AT: Correlation between epithelial cell proliferation and histological grading in gastric mucosa. Clin Pathol 1999, 52:367-37|

10. Brenes F, Ruiz B, Correa P, Hunter F, Rhamakrishnan T, Fontham E, Shi TY: Helicobacter pylori causes hyperproliferation of the gastric epithelium: pre- and post-eradication indices of proliferating cell nuclear antigen. Am J Gastroenterol I993, 88: I 870-5

II. Bechi P, Baizi M, Becciolini A, Maugeri A, Raggi CC, Amorosi A, Dei R: Helicobacter pylori and cell proliferation of the gastric mucosa: possible implications for gastric carcinogenesis. Am J Gastroenterol 1996, 91:27|-276

12. Lipkin M: Biomarkers of increased susceptibility to gastrointestinal cancer: new application to studies of cancer prevention in human subjects. Cancer Res 1988, 48:235-45

13. Lynch DA, Mapstone NP, Clarke AM, Jackson P, Dixon MF, Quirke P, Axon AT: Cell proliferation in the gastric corpus in Helicobacter pylori associated gastritis and after gastric resection. Gut 1995, 36:35I-3

14. Fan XG, Kelleher D, Fan XJ, Xia HX, Keeling PWN: Helicobacter pylori increases proliferation of gastric epithelial cells. Gut 1996, 38:19-22

15. Takagi A, Watanabe S, Igarashi M, Koike J, Hasumi K, Deguchi R, Koga Y, Miwa T: The effect of Helicobacter pylori on cell proliferation and apoptosis in gastric epithelial cell lines. Aliment Pharmacol Ther 2000, I4(Suppl I): | 88-92

16. Wagner S, Beil W, Westermann J, Logan RP, Bock CT, Trautwein C, Bleck JS, Manns MP: Regulation of gastric epithelial cell growth by Helicobacter pylori: evidence for a major role of apoptosis. Gastroenterology 1997, I 1 3: 1836-47

17. Chang K, Fujiwara Y, Wyle F, Tarnawski A: Helicobacter pylori toxin inhibits growth and proliferation of cultured gastric cells-Kato III. J Physiol Pharmacol I 993, 44: 17-22

18. Smoot DT, Wynn Z, Elliott TB, Allen CR, Mekasha G, Naab T, Ashktorab $\mathrm{H}$ : Effects of Helicobacter pylori on proliferation of gastric epithelial cells in vitro. Am J Gastroenterol I999, 94: I 508-15 II

19. Yamaoka Y, Kita M, Kodama T, Sawai N, Kashima K, Imanishi J: Induction of various cytokines and development of severe mucosal inflammation by cagA gene positive Helicobacter pylori strains. Gut | 997, 4 |:442-45 |

20. Peek RM, Miller GG, Tham KT, Perez Perez GI, Zhao X, Atherton JC, Cover TL, Blaser MJ: Heightened Inflammatory response and cytokine expression in vivo to cagA+ Helicobacter pylori strains. Lab lnvest 1995, 73:760-770

21. El-Omar EM, Carrington M, Chow WH, McColl KE, Bream JH, Young HA, Herrera J, Lissowska J, Yuan CC, Rothman N, et al: InterleukinI polymorphisms associated with increased risk of gastric cancer. Nature 2000, 404:398-402

22. Machado JC, Pharoah P, Sousa S, Carvalho R, Oliveira C, Figueiredo C, Amorim A, Seruca R, Caldas C, Carneiro F, et al: Interleukin Ib and interleukin Irn polymorphisms are associated with increased risk of gastric carcinoma. Gastroenterology 2001, 1 21:823-9

23. Kuipers EJ, Lundell L, Klinkenberg Knol EC, Havu N, Festen HP, Liedman B, Lamers CB, Jansen JB, Dalenback J, Snel P, et al: Atrophic gastritis and Helicobacter pylori infection in patients with reflux esophagitis treated with omeprazole or fundoplication. N Eng J Med 1996, 334:1018-1022

24. El-Omar EM: The importance of interleukin Ibeta in Helicobacter pylori associated disease. Gut 200I, 48:743-7

25. Pearson G, Robinson F, Beers Gibson T, Xu BE, Karandikar M, Berman K, Cobb MH: Mitogen-activated protein (MAP) kinase pathways: regulation and physiological functions. Endocr Rev 200I, 22:153-83

26. Stepan VM, Sawada M, Todisco A, Dickinson CJ: Glycine-extended gastrin exerts growth-promoting effects on human colon cancer cells. Mol Med 1999, 5:147-159

27. Tanabe K, Okuya S, Tanizawa Y, Matsutani A, Oka Y: Leptin induces proliferation of pancreatic beta cell line MIN6 through activation of mitogen-activated protein kinase. Biochem Biophys Res Commun 1997, 241:765-8

28. Stepan VM, Krametter DF, Matsushima M, Todisco A, DelValle J, Dickinson Cl: Glycine-extended gastrin regulates HEK cell growth. Am J Physiol 1999, 277:R572-81
29. Stepan VM, Dickinson CJ, Del Valle J, Matsushima M, Todisco A: Cell type-specific requirement of the MAPK pathway for the growth factor action of gastrin. Am J Physiol 1999, 276:GI 363-72

30. Prinz C, Neumayer N, Mahr S, Classen M, Schepp W: Functional impairment of rat enterochromaff in-like cells by interleukin I beta. Gastroenterology 1997, I I 2:364-375

3I. Beales I, Calam J: Stimulation of IL-8 production in human gastric epithelial cells by Helicobacter pylori, IL-I $\beta$ and TNF- $\alpha$ requires tyrosine kinase activity, but not protein kinase $C$. $C y$ tokine | 997, 9:5 |4-520

32. Beales IL, Calam J: Helicobacter pylori stimulates granulocytemacrophage colony-stimulating factor (GM-CSF) production from cultured antral biopsies and a human gastric epithelial cell line. Eur / Gastroenterol Hepatol 1997, 9:45|-455

33. Dippold WG, Klingel R, Kerlin M, Schwaeble W, Meyer zum Buschenfelde $\mathrm{KH}$ : Stimulation of pancreas and gastric carcinoma cell growth by interleukin 3 and granulocyte-macrophage colony-stimulating factor. Gastroenterology 1991, 100:1338-44

34. Dippold W, Meyer zum Buschenfelde KH: Proliferation of gastrointestinal carcinoma cells by $\mathrm{T}$ lymphocyte factors interleukin-3 and granulocyte-macrophage colony-stimulating factor. Immunol Res 1991, 10:258-60

35. Suzuki H, Mori M, Seto K, Shibata F, Nagahashi S, Kawaguchi C, Suzuki M, Matsui H, Watanabe K, Miura S, et al: Rat CXC chemokine GRO/CINC-I paradoxically stimulates the growth of gastric epithelial cells. Aliment Pharmacol Ther 2000, 1 4:94-100

36. Brooks JW, Mizel SB: Interleukin-I and signal transduction. Eur Cytokine Netw 1994, 5:547-56I

37. Beales I, Calam J: Interleukin-I $\beta$ and tumour necrosis factor- $\alpha$ inhibit acid secretion in cultured rabbit parietal cells by multiple pathways. Gut 1998, 42:227-234

38. Beales IL, Calam J: Inhibition of carbachol stimulated acid secretion by interleukin Ibeta in rabbit parietal cells requires protein kinase C. Gut 200I, 48:782-9

39. Dobson PR, Skjodt H, Plested CP, Short AD, Virdee K, Russell RG, Brown BL: Interleukin-I stimulates diglyceride accumulation in the absence of protein kinase C activation. Regul Pept 1990, 29:109-116

40. Tominaga K, Higuchi K, Tsuno M, Watanabe T, Fujiwara Y, Kim S, Arakawa T, Iwao H, Kuroki T: Induction of signal transduction pathways in rat gastric epithelial cells stimulated with interleukin-I beta. Aliment Pharmacol Ther 2000, I 4(SuppI I):I0 I-8

4I. Tominaga K, Arakawa T, Tsuno M, Kim S, Iwao H, Kuroki T: Increased mitogen-activated protein kinase activities stimulated with interleukin-I-beta and mechanism(s) of the kinase signaling pathways in rat gastric epithelial cells. Digestion 2000, 61:30-8

42. Nakamura E, Takahashi S, Matsui H, Okabe S: Interleukin-lbeta inhibits growth factor-stimulated restoration of wounded rat gastric epithelial cell monolayers. Dig Dis Sci 1998, 43:476-84

43. Beales I, Calam J, Post L, Srinivasan S, Yamada T, Delvalle J: Effect of tumor necrosis factor- $\alpha$ and interleukin-8 on somatostatin release from canine fundic D-cells. Gastroenterology 1997, I | 2:136-143

44. Beales ILP, Post L, Calam J, Yamada T, DelValle J: Tumor necrosis factor alpha stimulates gastrin release from canine and human antral G-cells: possible mechanism of the Helicobacter pylori-gastrin link. Eur J Clin Invest 1996, 26:609-II

45. Weigert N, Schaffer K, Schusdziarra V, Classen M, Schepp W: Gastrin secretion from primary cultures of rabbit antral $\mathbf{G}$ cells: stimulation by inflammatory cytokines. Gastroenterology 1996, I I 0:147-54

46. Suzuki T, Grand E, Bowman C, Merchant JL, Todisco A, Wang L, Del Valle J: TNF-alpha and interleukin I activate gastrin gene expression via MAPK- and PKC-dependent mechanisms. Am J Physiol Gastrointest Liver Physiol 200 I, 28 I:G I 405-12

47. Correa P: Human gastric carcinogenesis: a multistep and multifactorial process-First American Cancer Society Award Lecture on Cancer Epidemiology and Prevention. Cancer Res 1992, 52:6735-6740

48. Beales IL, Davey NJ, Pusey CD, Lechler RI, Calam J: Long-term sequelae of Helicobacter pylori gastritis. Lancet 1995, 346:38I382

49. Peek RM Jr, Moss SF, Tham KT, Perez Perez GI, Wang S, Miller GG, Atherton JC, Holt PR, Blaser MJ: Helicobacter pylori cagA+ 
strains and dissociation of gastric epithelial cell proliferation from apoptosis. J Natl Cancer Inst 1997, 89:863-868

50. Peek RM Jr, Wirth HP, Moss SF, Yang M, Abdalla AM, Tham KT, Zhang T, Tang LH, Modlin IM, Blaser MJ: Helicobacter pylori alters gastric epithelial cell cycle events and gastrin secretion in Mongolian gerbils. Gastroenterology 2000, I I 8:48-59

51. Saperas E, Cominelli F, Tache Y: Potent inhibition of gastric acid secretion by intravenous interleukin- $I$ beta and - $I$ alpha in rats. Peptides 1992, 13:221-226

52. Sipponen $\mathrm{P}$, Hyvarinen $\mathrm{H}$ : Role of Helicobacter pylori in the pathogenesis of gastritis, peptic ulcer and gastric cancer. Scand J Gastroenterol Suppl 1993, 196:3-6

53. Stockbruegger RW, Cotton PB, Menon GG, Beilby JO, Bartholomew BA, Hill MJ, Walters CL: Pernicious anaemia, intragastric bacterial overgrowth, and possible consequences. Scand J Gastroenterol 1984, 1 9:355-64

54. Jobson TM, Billington CK, Hall IP: Regulation of proliferation of human colonic subepithelial myofibroblasts by mediators important in intestinal inflammation. J Clin Invest 1998, I 01:2650-7

\section{Pre-publication history}

The pre-publication history for this paper can be accessed here:

http://www.biomedcentral.com/1471-230X/2/7/prepub

Publish with BioMed Central and every scientist can read your work free of charge

"BioMedcentral will be the most significant development for disseminating the results of biomedical research in our lifetime." Paul Nurse, Director-General, Imperial Cancer Research Fund

Publish with BMC and your research papers will be:

- available free of charge to the entire biomedical community

- peer reviewed and published immediately upon acceptance

- cited in PubMed and archived on PubMed Central

- yours - you keep the copyright 